\title{
EMANCIPATORY PEDAGOGY AND COMMUNITY WORK: THE TEACHING-PRACTICE NEXUS
}

\author{
Vishanthie Sewpaul, Ingrid Osthus, Christopher Mhone
}

\section{INTRODUCTION}

Teaching and learning entail a relational process whether it begins with the educator, in interaction with individuals, small groups or larger groups in the classroom. This relational process is largely influenced by the worldviews of educators and the kinds of pedagogical strategies adopted. While students bring to the educational context their own histories and socialised experiences that serve as both barriers and facilitators to radical pedagogy, the educator shapes the culture, tone and ethos for teaching and learning. The following components constitute teaching excellence: enthusiasm; power to stimulate students' thinking and imagination; love of knowledge and passion; linking theoretical knowledge to daily lived experiences; positive regard for students; courage to engage students in controversial debate and discussion; clarity of presentation; being prepared and organised; providing a sense of hope for the future (East \& Chambers, 2007; Freire, 1970, 1073; Giroux 1983; Gramsci, 1971; Sewpaul, 2003; Sewpaul, 2004a; Sewpaul 2004b); being a good role model (Jirovec, Ramanathan \& Alvarez Rosegrant, 1998); and being able to create a sense of solidarity in the classroom where teaching and learning become a process of cooperative enquiry (Reason, 1994). Parker Palmer's (cited in East \& Chambers, 2007:814) first principle is: "We teach who we are; good teaching cannot be reduced to technique; good teaching comes from the identity and integrity of the teacher."

In order to ensure that teaching and learning become and remain a relational process it is critical that educators make an attempt to understand the life-worlds and the socio-demographic backgrounds of students. Working with demographic data and the biographies of students can prove particularly useful especially in a discipline such as social work, where mutual empathy (Edwards \& Richards cited in East \& Chambers, 2007) is important. To teach students about social problems assuming that the problems lie "out there", beyond the classroom, beyond the individuals whom we are engaging with in our classroom and supervisory contexts, is a gross misrepresentation of how context mediates what and how students learn and what students perceive the main purposes of education to be. In keeping with the participatory nature of the educational experience, this paper represents the voices of the educator and the students.

\section{AN EDUCATOR SPEAKS: THE VOICE OF VISHANTHIE}

In an attempt to understand students better, I worked with their biographies over the past 15 years; students wrote assignments, locating themselves within their historical and contemporary socio-cultural, economic and political contexts, paying particular attention to the intersection of criteria such as race, class, gender, sexual orientation, urban-rural location, nationality, language and disability. These provided invaluable insights into the life-worlds of students. However, it also placed a moral responsibility on the educator as students often disclosed a range of problems including experiences of sexual and physical abuse, rape and loss of close family members. Expressions of depression and suicidal tendencies were also present and I would desperately hope, as I marked over a weekend, that it was not already too late to reach out. In addition to the biographies, which provided a goldmine of qualitative data, in $2010 \mathrm{I}$ administered a questionnaire in the classroom that was filled in by 260 students registered for 
an introductory course in Social Work in their second week, first semester of their first year of study at university

As anticipated, 74\% were female. Almost all students were African Black (94\%), with a few Indians and Coloureds; there were no White students registered for the Social Work degree. Only a small minority (7\%) had English as their first language; $72 \%$ were isiZulu speaking, followed by Xhosa (4\%), with the rest speaking French, Swahili, Tsonga and Tswana. As they are studying in an English-medium institution, the implications of this are huge - simply in terms of coping with studying in what might be a $2^{\text {nd }}$ or $3^{\text {rd }}$ language, apart from the challenges linked to the cultural specificities of the different language groups.

The majority fit into the category of late adolescence to early adulthood, 19 to 25 years (58\%), followed by the 16-18 year group (36\%). If we considered no other variable, except age - with the full appreciation that adolescence brings its own turmoil as young people negotiate complex issues around identity, career choice, sexuality and the uncertainties and anxieties inherent in the formation of intimate relationships - we realise that teaching is an exceptionally tough and demanding job. Educators often have to tread a fine line between extending care and compassion, setting boundaries and helping students to balance their new-found freedom with responsibility as a parent would, and respect students as independent young adults. (Many are beyond the gaze of parents/caregivers for the first time as they enter tertiary education, with many of them leaving home for the first time.) Teaching in the age of HIV/AIDS and in the face of unplanned pregnancies in the South African context means that we cannot abdicate the responsibility to educate students about these salient issues - we cannot teach in a distant intellectual way, but in ways that help students connect with issues on emotional and spiritual levels in an attempt to translate understanding into behavioural changes. While less than $2 \%$ of the students were married, $14 \%$ were parents - of the 37 students who were parents, $68 \%$ had one child, $16 \%$ had two children, $5 \%$ had three children or more, $11 \%$ did not specify the number of children they had.

Fifty-five percent came from rural areas, $42 \%$ urban and 3\% from informal settlements; $44 \%$ of the students had no piped water in their homes and $31 \%$ had no electricity. These are privileges that are taken for granted in an urban context, where the university is located.

A minority (33\%) grew up with both parents; $26 \%$ with mothers only; $1.5 \%$ with fathers only; $13 \%$ with mother and grandparents; $12 \%$ with their grandmothers and the rest with siblings, relatives, foster parents and non-related people. Most notable was the absence of fathers. Women - mothers or grandmothers [51\%] - bore the responsibility for child rearing. Thirty percent of the students had no one employed in the family.

The majority of students experienced loss from AIDS $-84 \%$ experienced loss of relatives, $5.6 \%$ loss of fathers, $5 \%$ of mothers and $7 \%$ of siblings; $51 \%$ of the students experienced multiple losses, with $12 \%$ having had lost more than eight known people through HIV/AIDS.

The demographics are disturbing considering that we would expect students to perhaps represent those who are more resourceful to get into tertiary education in the first instance. The backgrounds of the students mirror that of South Africa, reflecting high rates of poverty and inequality (only $8 \%$ of the students came from a middle-income bracket), absent fathers, female-headed households, having to contend with lack of basic resources and the often multiple losses linked to HIV/AIDS (Amoateng \& Heaton, 2007).

While poverty in itself is destructive and constitutes an assault on one's being, we must be even more concerned about the potentially explosive and destructive consequences of inequality 
(Diamond, 2005; Fanon, 1970). South Africa is now the one of the most unequal countries in the world. ${ }^{1}$ The gaps both across the different race groups and within groups are widening. Apartheid ensured differential access to resources for the different race groups, thus impacting most negatively on African Black people, but there is now a rapidly emerging Black middle class. The Department of Social Development (2003) found that African households possessed only two of six amenities listed, compared to a median of four in Coloured households and a median of six in Indian and White households. These amenities were flush toilets, telephone, electricity from the mains, refuse collection, piped water and ownership of a car.

These societal patterns and macro-level dynamics play themselves out in the classroom and in students' field practice education. The challenges that they present for education are: (1) the normalisation of poverty and inequality, and the internalisation of oppression (Freire; 1970; 1973; Mullaly, 2002; Pheterson, 1986) among students who have grown up with disadvantage; and (2) the normalisation of privilege (Giroux, 1997; Flood \& Pease, 2005). Pheterson (1986:148) defined internalised oppression as "the incorporation and acceptance by individuals within an oppressed group of the prejudices against them within the dominant society". The normalisation of privilege, referred to as "internalised domination" is defined as "the incorporation and acceptance by individuals within a dominant group of prejudices against others" (Pheterson, 1986:147). Both these are linked to the common-sense assumptions that we hold on account of the ideological hegemony imposed by capitalism and the state apparatus (Althusser, 1971; Gramsci, 1971). We are products of our socio-economic, cultural and political contexts, which play a powerful role in controlling our consciousness. The danger of these assumptions is that as members of either group we reproduce class relations, oppressions and privileges without being fully aware of our complicit role in their reproduction. This is particularly salient in social work, in that local students who have normalised poverty and inequality and/or privilege expect nothing better for service users - the socio-structural arrangements are deemed to be the natural state of the world. It is generally international students who have grown up in more egalitarian contexts, such as Sweden and Norway, who respond with a sense of moral outrage when confronting hunger, lack of access to medical treatment and the high costs of education. It is a system that they have difficulty comprehending, as they have taken their relative equality and access to resources for granted.

Based on the understanding that one's own subject position in the world influences how one understands and engages with the world, attempts are made in the classroom and in supervision - through dialogue, debate, reflexive discussion, student presentations and assignments designed to produce reflexive thinking to help students transform common sense into good sense - to subject taken-for-granted common sense assumptions to empirical and critical interrogation (Gramsci, 1971). The main aim is to help students to understand and challenge external sources of oppression (Dominelli, 2002; Freire, 1970, 1973; Mullaly, 2002; Sewpaul, 2003) and to understand and undo sources of privilege (Flood \& Pease, 2005; Giroux, 1997; Pease, 2010). In encouraging students to engage with their own biographies, I share my own (Sewpaul, 2003) with them, citing Giroux's (1997:159) contention that "An examination of the historical and social constructs of our lives helps to ... rewrite the complex narratives that make up (our) lives", thus enabling us to be the authors and editors of our lives. The emphasis is

\footnotetext{
${ }^{1}$ The gini coefficient is a measure of inequality based on income distribution and wealth distribution. 0 corresponds to perfect equality and 1 corresponds to perfect inequality. With a gini coefficient of 65.0, South Africa is $135^{\text {th }}$ in the list of 136 countries; only Namibia has a less equal distribution of income. Suddenwalk posted $6^{\text {th }}$ June 2011 (http://suddenwalk.com/2011/06/ - accessed 13/09/2011).
} 
simultaneously on human agency and the impact of substantial unfreedoms, for example, the constraints imposed by lack of food, shelter, education and health on our lives, and on the relationship between freedom and responsibility (Sen, 1999). While I have taught a designated course on Anti-oppressive Theory and Practice, emancipatory education and critical social work underlie all that I teach. Most students find both the content and the pedagogical strategies appealing; they report that this approach provides them with validating and liberating experiences and that it challenges their thinking. Where students come into the classroom with a radical orientation, the emancipatory ideals embraced by the educator serves to ignite and intensify what already exists, as reflected in the voice of Ingrid.

\section{A STUDENT SPEAKS: THE VOICE OF INGRID}

Allen, Floyd-Thomas and Gillman (2001: 320) discuss how they had to teach their students "how to want the social justice that is the catalyst for transformation". In my case, the seeds for seeking justice already existed. The sufferings of the world pained me and I wanted to make a difference. The beginnings of critical understanding in me was influenced by the Manavodaya Institute in India, where radical participation by the poorest village people was championed and the position of the expert from the West or the North challenged (Vidyarthi \& Wilson, 2008). This prompted me to make major life changes and to seek education outside of Europe, and it was an important factor in my choice to leave my safe space in Norway and move to South Africa to study.

Upon arrival in South Africa, I believed in my ability to engage in action directed towards the realisation of social justice ideals. This belief was soon shaken, as I was overwhelmed by racial tension and the oppressive meanings of being "white" (Osthus, 2008).

An integral part of anti-oppressive social work is to overcome internalised oppression, to expose and challenge the myth of self-blame and individual inadequacy as explanations for social problems and to reveal underlying structural causes (Payne, 2005; Sewpaul, 2005). It is naïve to assume that we can contribute to the processes of transformation in other people if we haven't experienced the deconstruction and reconstruction of our own identities. These processes are thus also central to emancipatory education (Sewpaul, 2003). De Maria (1992) suggests that the first step in such a transformative process is a classroom exercise of cognitive reorientation to the root causes of social problems. While "cutting through ideological mystifications and misrepresentations to first causes" (De Maria, 1992:238) is necessary, the educator must, parallel to the teaching, create a space for personal reflection on the students' own lives and identities. We are complete human beings, and even in our professional role as social workers we bring with us our embodied selves with everything that entails.

In my first year Vishanthie taught a course on "Human behaviour and the social environment". It was underpinned by critical theory and it "cut through" to the "first causes" of social problems. Integrated in the course were reflective exercises that required us as students to relate the material to ourselves and to reflect on privilege and oppression in our own lives. As other educators and students have pointed out (Campbell, Scott-Lincourt \& Brennan, 2008; Allen et al., 2001), this is a challenging and at times painful process. I was already struggling to find a way to live with my whiteness in such a contested racial space. As the only white student in class, I felt trapped in the guilt of whiteness. Dominelli (2002) draws attention to how paralysing it can feel to be identified as an oppressor, especially when it is difficult to get out of that particular social category. There was nothing I could do to change my skin colour and I experienced this as an existential crisis. 
It was a small, one-page reflection paper that turned the process into a liberating one for me. We were asked to write a summary of our understanding of Giroux's concept "insurgent multiculturalism" and then reflect on its meaning for our own lives. Until then, I had felt increasingly alienated from my desire for social justice. As an evil oppressor, I saw no appropriate space for me to participate. But Giroux included dominant groups in the conscientisation processes, and called for them (that is, for me) to "examine, acknowledge, and unlearn their own privilege" (Giroux, 1997, cited in Sewpaul, 2003:313).

My reflections did not take place in a vacuum. Beside the geographical and political context, of equal importance was the context of the humane relationship with the educator/mentor. One aspect of that was our collective experience as a class of Vishanthie. She was woman, she was bold, and this made an impression. Another aspect is my personal experience. I needed to be seen as an individual, and not merely as a part of a huge class. When Vishanthie looked me in the eyes and said: "It is not your fault", it helped me to liberate myself from my guilt of belonging to a privileged social category. I needed the personal affirmation and not merely an abstract theory.

Apart from the power of her words to me, the congruence between the theory being taught and her validation of me contributed to my emancipation. It was critical theory and anti-oppressive practice in action and these related to my own personal challenges. The transformation and liberation that I experienced rekindled the passion and desire to extend the liberation to others.

Furthermore, the role of the mentor has been crucial in transferring the learning into practice, of making the theoretical knowledge cascade into the field. She created the space for critical action for me and the other students in our practice group. She had the authority to cut through, and help us navigate, some of the bureaucratic obstacles, and she had the passion and personal integrity to model and to inspire us in our fieldwork and our endeavour to integrate the personal, the professional and the political (Humble, Solomon, Allen, Blaisure \& Johnson, 2006). This was especially crucial given the generally unsupportive environment in which we as a class were expected to practice. This was a recurring theme in discussions with my friends, who were exhaustingly frustrated with the contradiction between their wish to integrate emancipatory approaches in their fieldwork and the conventional conformist social work practice that was demanded from them. Without Vishanthie's practical interventions to adjust the teaching and practice structure to anti-oppressive work and critical action (for example, to change our submission requirements to reflect holistic, integrated micro and macro strategies and not separate our work into distinct casework, group work and community work methods), my own intentions and efforts as well as her psychosocial support would have been minimised. That is not to say that the psychosocial support was of lesser value; her true care for us as whole beings, and not merely academically as students, has been absolutely crucial to my own journey. The mentoring relationship was the safe space where I could figure out all the contradictions of identity, privilege and oppression in my own life. It was the space where I could experience and live anti-oppressive practice (Campbell et al., 2008), and the space where I could identify inequities and injustices and wrestle with the way to act and live with integrity (Humble et al., 2006).

An important note here is my experience of the relationship with my supervisor/mentor as one of complete acceptance. I was not concerned about the appropriateness of the challenges I experienced personally and professionally. I felt that all my emotions and reactions were embraced. Rossiter and others (cited in Hölscher \& Sewpaul, 2007:185) speak of "the messy world of practice" as opposed to a conventional conceptualisation of ethics. It applies just as 
much to the conventional expectations of teaching and learning. If I were concerned with the "check-list" of assessment criteria, which encourages students to display certain behaviours and actually discourages honesty, I would not have expressed my true challenges in the field. However, the openness from the mentor invited me to share the messiness of real life and of my emotions as we engaged in participatory research and practice with children and youths on the streets.

As part of the field practice education experience Vishanthie asked that we keep journals. Constantly reflecting on the processes and events I experienced has helped me in several ways. Firstly, it has helped me to incorporate critical thinking or critical analysis into my practice and research. In the hustle and bustle of events I easily get absorbed by the here-and-now and journaling helps me to take a step back and look at situations from different perspectives. It has thus helped me to look beyond the personal problem. Secondly, it is a practical tool for selfreflection. It has helped me to constantly be aware of power dynamics, both among my colleagues and myself and the people I work with. It has furthermore helped me always to align what I am doing with my intentions; to scrutinise what is happening and compare that with critical theories and the goals of social justice. Both forms of self-reflection are essential for critical practice (Humble et al., 2006). Critical reflection requires a lot from one and it is not easy to incorporate it into the heavy workload and the hectic working day with too many demands and too few resources, which is the daily reality and dilemmas of many practising social workers (Hölscher \& Sewpaul, 2007). Journaling is time consuming, but I have found the gain to outweigh the pain. It has been of the utmost value during my field practice education as an undergraduate student. Even though it is no longer a formal requirement, I continue journaling and I intend to continue the habit into my working life as well. I cannot see the critical practitioner in me survive without this tool for reflection.

\section{A STUDENT SPEAKS: THE VOICE OF CHRIS}

Coming from Malawi, one of the poorest countries in the Southern African region, to the University of KwaZulu-Natal's School of Social Work and Community Development allowed me to embark on a personal journey, a path of self discovery. My introduction to the emancipatory theories of Antonio Gramsci, Henry Giroux and Paulo Freire by Vishanthie in my first year at UKZN enabled me to understand that I am deeply embedded in structures cultural, economic, political - that constantly shape my worldview. I began to appreciate that some of the thoughts and decisions that I felt were my "own" were expressions of dominant socialised responses. My engagement in anti-oppressive discourse with fellow students and the influence of a supervisor, whom I constantly look up to for inspiration and guidance, had a profound impact on the deconstruction and reconstruction of my own identity. Growing up in Malawi in the 1980s and 1990s, I was constantly reminded of obedience, loyalty, discipline and unity - termed the four cornerstones of Malawi by the dictatorial regime. This was indoctrinated into Malawians by the late former life president, Dr Hastings Kamuzu Banda. The emphasis was on unconditional subjugation to authority; no one had the power to question the decisions that were made by the political powers. The impact of the authoritarian politics manifested in our homes; adults had the utmost power in decision making and as children we had no say. Given the male dominance, the decisions that fathers made in our homes were as powerful as a bill assented to by the President. The assertion of such authority and indoctrination and the inculcation of powerlessness was accepted as normal. The normality of this was equally highlighted in my teenage life when I went into a seminary where we were constantly told that we could not question the word of our superiors. It was easy to get 
suspended or dismissed for displaying behaviour that did not reflect priestly life and we were constantly reminded by our priests that to survive in the seminary 'you do not have to raise your head high otherwise you get chopped'. Such were the systems that shaped my worldview. My interaction with my supervisor and other lecturers through emancipatory education allowed me to see alternative worldviews that were more empowering and allowed me to see that I could be free from mental slavery.

While I valued the emancipatory approaches in class and how they linked to my own life, I began to develop a deeper appreciation for the more substantive aspects of this in the field practice context. Working with children and youths living on the streets over a two-year period allowed me to experience the power of emancipatory social work. It was not easy on my part to undo established conventions about what constitutes "good professional" social work (I had some practice experience in Malawi before entering the Social Work programme at UKZN). However, I made a conscious attempt to free myself from taken-for-granted practices that might actually hinder progress and development. This entailed my having to challenge and work against my identity as an expert. The challenges were two sided. Participation in decision making was foreign to Malawian children and youths - they were accustomed to professionals making decisions for them and to top-down approaches. Given their status as "street children", there is an assumption that they cannot be trusted to make sensible decisions. Getting them to see and believe that we were interested in genuinely working with them was difficult. They were surprised that we wanted them to participate fully in every phase of the work that we were doing. We had to be consistent in our approach and we had to work hard to get them to understand that they functioned within a system that needed to change, that they could assert some measure of power and control over processes, and that these processes had to be informed by their own stories of life on the streets.

Once - after several group discussions about the violence and abuse experienced at the hands of the metro police - they asked us as the facilitators to leave the hall. One of the youths followed us, saying he saw no point in discussing the matter without us present. He believed they had neither the power nor the capacity to deal with such a major and politically volatile issue. Recognising that "power and/or powerlessness are reproduced in everyday life experiences" (Sewpaul, 2003:304), we encouraged him to return to the group so that they could discuss the way forward. Reason and Bradbury (cited in Reason, 2008:207) confirm that "this political form of participation affirms people's right and ability to have a say in decisions which affect them [...]. It asserts the importance of liberating the muted voices of those held down by class structures and neo-colonialism, by poverty, sexism [and] racism". When we rejoined the group, they presented us with clear plans of action and they went on to successfully implement the plans, all of which proved to be extremely validating for them. Radical or emancipatory approaches to human development help people to deal with obstacles though their own efforts and initiatives (Sen, 1999). With human agency and commitment one can bring about radical change through improving societal conditions. The children and youths in this instance felt empowered enough to bring together the various organisations that work with them to deal with the problems of violence in relation to the metro police (Sewpaul, Mhone \& Osthus, in press).

The ability to work at this level with children living on the streets needed a great deal of trust both within the students' work team (there were five students), between the supervisor and students, and between the team and the children. We had to work on building mutual trust at various levels. It was time consuming, chaotic and emotionally demanding, so much so that at times there was the temptation to take the easier conventional route - make the decisions and 
simply let the children fall in line with our plans. Being constantly aware that the processes were equally, if not more, important as the goals, we chose the more difficult route, with the support and validation of our efforts by the supervisor. We were also fortunate that we had what Sharma (1999) called a "beacon of light" that helped us retain our participatory and emancipatory ideals. The experience that Ingrid and I had at Butterflies in India, working with street children, allowed us to see that true participation was possible, and we consistently communicated this message to other team members and to the children. Our experience at Butterflies made us realise that by giving up power and our privileged positions, we could give the children and youths a chance to gain power and control over their lives. We witnessed Butterflies engaging children as competent persons who could be trusted to manage change processes. The children managed their own bank; they were bank managers, oversaw the approval of loans, and they appraised business plans and repayment strategies. Butterflies served as our hope and our inspiration. We thought, perhaps in our naivety, that if children in India could do it, we could as well and made some abortive attempts to emulate Butterflies. The challenges and complexities of these attempts are detailed in Sewpaul \& Osthus (2009).

As students we faced our own challenges. Most of us came from family backgrounds that did not promote child participation and the children themselves did not understand the process. In order to deal with the challenges and talk about our own possible blocks to emancipatory social work, the team had regular weekly meetings, especially in the first few months of the inception of the programme and we had regular weekly supervision. We engaged in the process of what Reason (1994) calls "co-operative enquiry" - our meetings became the context for reflections on our work and our encounters with children on the streets. The cooperative enquiry method cut across three levels - interaction with the supervisor on a weekly basis; weekly team meetings among the student group; and weekly (sometimes daily) outreach work and meetings with children on the streets. The children were involved with us as co-participants and coresearchers, consistent with the method of co-operative enquiry, the power of which is described by Reason (1994:327) as follows:

"One can only do research on persons in the full and proper sense of the term if one addresses them as self-determining, which means that what they do and what they experience as part of the research must be to some significant degree determined by them. So in co-operative inquiry all those involved in the research are both co-researchers, whose thinking and decision-making contributes to generating ideas, designing and managing the project, and drawing conclusions from the experience; and also co-subjects, participating in the activity which is being researched."

The constant appraisal of our epistemologies and why we adopted a participatory approach reaffirmed our strategies. Central to the meetings and supervision was us reflecting on own social positions, the power we had as students, how we impacted on each other as a team, and how our own subject locations in relation to disadvantage and privilege influenced our work with the children and youths living on the streets.

There were also power dynamics within the student team that had to be addressed. There were four women; I was the only male. Two of the four women were African and isiZulu speaking; one was Indian and the other a white foreign national who did not speak isiZulu. I am a Black man, a foreign national with little understanding of isiZulu. The two isiZulu-speaking women had easier access to the children, especially during the initial stages of the work. We had an agreement that the meetings with the children would be conducted in English and translated into isiZulu either by a child who understood English or by one of our isiZulu-speaking team 
members. However, there were times when a great deal of discussion took place in isiZulu without translation, and this made me and Ingrid feel excluded and marginalised. The complexities of power dynamics in relation to language, race, gender, nationality and academic performance played themselves out in the team, in the work on the streets and in supervision at times. Ingrid, as described above, had to deal with the privilege - or at times assumed privilege - of her whiteness. We learnt that oppression and privilege work in complex ways and appreciated the power of context in determining privilege and minority status. While as a male I am usually part of a dominant and privileged group, as is Ingrid in terms of her whiteness, in this instance both of us were in minority positions.

However, given that we were taught to try to understand the dynamics of oppression and of privilege in our own lives, we were able to deal with issues for the most part constructively. There were times that we engaged in confrontational dialogue, which created temporary ruptures in the team that we had to work through. Emancipatory education and practice is about understanding one's own social position within which power and powerlessness are played out. Such awareness can help us disrupt the reproduction of oppressive relationships and it can have a powerful influence on how we engage with marginalised groups. The flexibility of approach that we adopted and the relative freedom that we enjoyed as students to manage our time and to make decisions did not detract from our sense of accountability. In fact, the flexibility and the freedom ensured that we lived up to the trust invested in us by the supervisor - a dynamic that we saw play itself out on the streets as well. The more the children on the streets experienced us as being trustful and validating of them, the more trustworthy they became and some of them became our protectors and guides as we ventured into new spaces on the streets.

Working with oppressed groups is an act of self-education in deconstructing our privileged social positions. While many students, including myself, experience marked disadvantage, we need to understand that we are generally in more privileged positions compared with the people whom we work with. This is particularly so when working with children on the streets who are labelled, discriminated against, poor and at the very bottom of the social stratification system. Our identities as experts can betray us even more in such instances. The exercise of consistent reflexivity enabled us to allow the children to take control of processes, with us as guides and facilitators. One of the major things that helped us retain this epistemology was the understanding of the intersection between the political and personal lives of children and our efforts to get the children to move beyond their own internalised negative self-perceptions and internalised oppression. As Cloward and Piven (cited in Mullaly, 1998:166) posit:

"We have to break with the professional doctrine that ascribes virtually all of the problems that clients experience to defects in personality development and family relationships. It must be understood that this doctrine is as much political ideology as an explanation of human behaviour. It is an ideology that directs clients to blame themselves for their travails rather than the economic and social institutions that produce many of them ... this psychological reductionism - this pathologizing of poverty and inequality - is, in other words, an ideology of oppression for it systematically conceals from people the ways in which their lives are distorted by the realities of class structure."

\section{CHALLENGES}

The above quotation is our raison d'etre for adopting emancipatory education and emancipatory social work strategies. Challenging oppression and/or privilege, even under the most conducive educational contexts, is extremely difficult. It becomes even more difficult 
when this ethos is not a shared one. A major obstacle to developing critical understanding and, especially, to living out that critical understanding in the practice field is the inconsistency with which it is taught. While some students, who perhaps already have an inclination towards it, may grasp it quickly and hold on to it throughout their education and in their working life, the majority of the students may not "convert" that easily (De Maria, 1992). It takes time and consistency to change paradigms and ways of working. While emancipatory approaches may be consistently and convincingly taught by a few lecturers, the message that students on the whole receive is one of compliance and conformity, thus warranting the scathing attack on contemporary social work education, with its emphasis on highly individualised views and lack of attention to the structural determinants of poverty and inequality.

The rigidity of the structure of the practice placement itself is a major block to making the theoretical knowledge of critical theory cascade into the field as critical action. The rigidity leaves little room and flexibility for the time-consuming and often messy and complex processes of true anti-oppressive and radical practice. Critical action does not fit nicely into a box, or on a standardised list of tasks and skills that can be assessed and ticked off within rigid and constricted timeframes. Such inconsistency, or the hypocrisy of the teaching structure, has the dangerous potential to defeat, or at least counteract, the whole transformative process (Campbell et al., 2008), making the emancipatory education efforts in the classroom futile.

The increasing commodification of education, the demand from university authorities to take in greater numbers of students, the greater bureaucratic controls and imposition of new managerialist and evidence-based practice are all inconsistent with the participatory, inclusive and student-centred approaches embraced in emancipatory education. Harkavy (2008:94) claims that commodification, with "education for profit [and] students as customers", represents a "clear and present danger to the democratic mission of education" (my emphasis). Referring to universities as "entrepreneurial, ferociously competitive, profit-making corporations", Harkavy (2008:96) argues that: "When universities openly and increasingly pursue commercialization, it powerfully legitimizes and reinforces the pursuit of economic selfinterest by students and contributes to the widespread sense among them that they are in college solely to gain career skills and credentials." How does one help students, in any sustained manner, to challenge taken-for-granted assumptions and transform common sense into good sense in the face of the onslaught of the new managerialism and neoliberalism? A charismatic teacher can attempt to do so in a classroom of 300 or more students, but what benefit is this if the student is not helped through some of the existential crises borne out of such awareness and how are the shifts in paradigm to be sustained and translated into practice?

We found that working against the normalisation of poverty and violence and abusive behaviours among the children and youths was a huge part of the discourse in supervision. In our efforts to tune into the life worlds of the children and have genuine empathic understanding, we sometimes found ourselves "going native" and we had to exercise caution in not normalising and condoning the various forms of destructive behaviours that we encountered. Trying to establish a balance between validating the children and youths as human beings, while confronting and challenging unacceptable - sometimes criminal -behaviour was not easy and we had to grapple with the tensions and ethical dilemmas related to this. It takes decided effort in small group contexts as well as skilled supervision to lend true meaning to emancipatory social work. Having to deal with increasing numbers of students, as educators we become a few steps removed from the field practice contexts, with agency supervisors taking greater responsibility for field supervision. While students might be exposed to emancipatory 
education in the classroom, some of their supervisors have not had that benefit and thus push students into more traditional moulds of professionalism.

A student's recent feeling of concern is captured in the following comment:

This email is regarding the practice that we are conducting at **** as fourthyear Social Work students. Unfortunatelyouragency supervisor still does not understand the significance for us to go to the streets or sit on the side of pavements and observe the lifestyle of the street children. We requested if we can at least leave the office and sit outside [...] because most of the children prefer to sit outside the organization during the day. Moreover, we have noticed that the children do not like to stay [...] for they know that they will be called into the office for a one-on-one interview [...], and they also feel jailed when they are in [...] because they are used to living under their own supervision. We are really concerned about this misunderstanding, because our main aim was to engage with the children and gain an understanding about their day-to-day survival strategies. Last week we requested the supervisor if we can join **** so that we could gain some experience on how the children reside on the streets, learn [...] outreach approach [...] and also build relationships with the children. However, she did not think that this was a good idea and declined our request.

The note was received after the university supervisor visited the agency twice and talked to the on-site supervisor about our worldviews and how we wanted to engage with the children. The students had been taught emancipatory education and they were really eager to put into practice the lessons learnt with regard to the social construction and power of the narrative, being involved and engaged, striving toward egalitarian relationships, and relational and postmodern ethics - rather than being bound by technical, positivist approaches to social work practice (Sewpaul, 2010). The agency supervisor acted within the constraints of what she had been taught and her socialised experiences; she was extremely well intentioned. She went out of her way to make the students feel welcome, allowed students to sit in on her interviews and she sat in on theirs. She often invoked the SACSSP Code of Ethics (www.sacssp.org) that the students were taught to interrogate critically (Sewpaul, 2010). The reports constantly reflected judgmental language - "uncooperative" and "difficult" children who were "lying" and who ran away from home "for no reason" - far from the assumptions that informed our work over the two-year period or the conclusions that we reached (Sewpaul \& Osthus, 2009). After more sustained contact with the agency, the field supervisor acknowledged that the traditional office interviews were not working. She expressed enthusiasm about working with the students in alternative ways of engaging with the children through drama, art, movies, collages and creative discussion, the development of plans of action with - rather than for - the children and to work within the life space of the children. There have been some decided changes and new ways of working; this needed to be nurtured and sustained and we hoped that it would continue on completion of the students' field practice.

\section{CONCLUSION}

We have highlighted the interface of students' own histories, their experiences of oppression and/or of privilege, and the supervisory context in influencing students' worldviews towards community-based practice and research. The pedagogical strategy was aimed at linking microeducational methodologies to theories of social change based on the integrative processes of action, critical reflection, theoretical knowledge and participatory community-based practice and research. Our experience demonstrates that emancipatory practices can be cascaded from 
the classroom and supervisory contexts to the field settings. This is by no means an easy process; it is complex, messy and chaotic, and it demands a great deal of commitment. It also requires our willingness to give up our identities as experts and our willingness to trust the capacities of the people with whom we work. It also needs students who share the passion, are committed and who do want to make a difference - that means students who choose the profession for the right reasons - not simply because they can access a scholarship and secure what they think would be an 8 to 4 job!

The cultural, socio-economic and political contexts of teaching and learning, and the bureaucratic demands linked to the commodification of education and new managerialism in a neoliberal world need to be challenged and changed to support more radical and emancipatory initiatives in classrooms and in student's field practice education. Having to fill in yet another form for the umpteenth time and to undergo yet another performance management appraisal, rather than spend time in constructive engagement with students, and in research and writing, does not augur well for emancipatory pedagogy.

\section{REFERENCES}

ALLEN, K.R., FLOYD-THOMAS, S.M. \& GILLMAN, L. 2001. Teaching to transform: from volatile to solidarity in an interdisciplinary family studies classroom. Family Relations, 50(4):317-325.

ALTHUSSER, L. 1971. Ideology and Ideological State Apparatuses. In: BREWSTER, B. (trans). Lenin and Philosophy, and Other Essays. London: New Left Books, 127-188.

AMOATENG, A.Y. \& HEATON, T.B. 2007. Families and households in post-apartheid South Africa: Socio-demographic perspectives. Cape Town, HSRC Press. [Online] Available: www.hsrcpress.ac.za. [Accessed: 12/09/2010].

BUTTERFLIES. [Online] Available: www.butterflieschildrights.org/profile.asp.

CAMPBELL, C., SCOTT-LINCOURT, R. \& BRENNAN, K. 2008. The real world of the Ivory Tower: linking classroom and practice via pedagogical modeling. Journal of Teaching in Social Work, 28(1/2):35-51

DE MARIA, W. 1992. On the trail of a radical pedagogy for social work education. British Journal of Social Work, 22(3):231-252.

DEPARTMENT OF SOCIAL DEVELOPMENT. 2003. Describing families for policy: Literature, archival and secondary research to support the development of family policy. Pretoria, HSRC.

DIAMOND, J. 2005. Collapse: how societies choose to fail or survive. London: Penguin Books.

DOMINELLI, L. 2002. Anti oppressive social work theory and practice. London: Palgrave Macmillan.

EAST, J. \& CHAMBERS, R. 2007. Courage to teach for social work educators. Social Work Education, 26(8):810-826.

FANON, F. 1970. The wretched of the earth. Harmondsworth: Penguin Books.

FLOOD, M. \& PEASE, B. 2005. Undoing men's privilege and advancing gender equality in public sector institutions. Policy and Society, 25(1):119-138. 
FOOK, J. 2002. Social work: critical theory and practice. London: Sage Publications.

FREIRE, P. 1970. The pedagogy of the oppressed. Harmondsworth: Penguin Books.

FREIRE, P. 1973. Education for critical consciousness. New York: The Seabury Press.

GIROUX, H.A. 1983. Theory and resistance in education: a pedagogy for the opposition. London: Heinemann Educational Books.

GIROUX, H.A. 1997. Pedagogy and the politics of hope: theory, culture and schooling. Colorado: Westview Press.

GRAMSCI, A. 1971. Selections from the prison notebooks. Edited and translated by HOARE, A. \& SMITH, G.N. London: Lawrence and Wishart.

HARKAVY, I. 2008. The role of universities in advancing citizenship and social justice in the $21^{\text {st }}$ century. Citizenship Education, 4:87-118.

HöLSCHER, D. \& SEWPAUL, V. 2006. Ethics as a site of resistance: the tensions between social control and reflection. In: HALL, N. (ed) Social Work around the World IV. Berne: IFSW Press.

HUMBLE, A.M., SOLOMON, C.R., ALLEN, K.R., BLAISURE, K.R. \& JOHNSON, M.P. 2006. Feminism and mentoring of graduate students. Family Relations, 55(1):2-15.

JIROVEC, R.L., RAMANATHAN, C.S. \& ALVAREZ ROSEGRANT, A. 1998. Course evaluations: what are social work students telling us about teaching effectiveness? Journal of Social Work Education, 34:229-236.

MULLALY, R. 1998. Structural social work: ideology, theory and practice. North Carolina: Oxford University Press.

MULLALY, R. 2002. Challenging oppression: a critical social work approach. Toronto: Oxford University Press.

OSTHUS, I.S. 2008. I'm White, I'm Evil. Poster Presentation at the Global Social Work Conference, Durban.

PAYNE, M. 2005. Modern social work theories. Basingstoke: Palgrave.

PEASE, B. 2010. Undoing privilege: unearned advantage in a divided world. London: Zed Books.

PHETERSON, G. 1986. Alliances between women: overcoming internalised oppression and internalised domination. Signs: Journal of Women in Culture and Society, 12(1):146-160.

REASON, P. \& TORBET, W.R. 2001. The action turn towards transformational social science. Concepts and Transformations, 6(1):1-37. [Online] Available: http://people.bath.ac.uk/ mnspwr/Papers/TransformationalSocialScience.pdf 17/07/2010.

REASON, P. 1994. Three approaches to participative inquiry. In: DENZIN, N.K. \& LINCOLN, Y.S. (eds) Handbook of qualitative research, 324-339. Thousand Oaks: Sage Publications. [Online] Available: http://people.bath.ac.uk/mnspwr/Papers/YVONNA.htm. [Accessed: 31/08/2010].

REASON, P. 2008. Doing cooperative inquiry. In: SMITH, J. (ed) Qualitative Psychology: a practical guide to methods. London: Sage Publications. [Online] Available: http://people.bath.ac.uk/mnspwr/paperslist.htm 17/07/2010. 
404

SEN, A. 1999. Development as freedom. Oxford: Oxford University Press.

SEWPAUL, V. \& OSTHUS, I. 2009. Critical action research: transferring lessons from the streets of New Delhi, India to the streets of Durban, South Africa. In: ZAVIRSEK, D. \& RAMON, S. (eds) Critical edge issues in social work and social policy: Ljubljana: Faculty of Social Work, University of Ljubljana.

SEWPAUL, V. 2003. Reframing epistemologies and practice through international exchanges: global and local discourses in the development of critical consciousness. In: DOMINELLI, L. (ed) Broadening horizons. International exchanges in Social Work, Aldershot: Ashgate.

SEWPAUL, V. 2004a. Emancipatory citizen education in action: discourse ethics and deconstruction (Part 1). Social Work/Maatskaplike Werk, 40(3):218-231.

SEWPAUL, V. 2004b. Emancipatory citizen education in action: creative teaching/learning options (Part 11). Social Work/Maatskaplike Werk, 40(4):336-343.

SEWPAUL, V. 2005. A structural social justice approach to family policy: a critique of the Draft South African Family Policy. Social Work/Maatskaplike Werk, 41(4):310-322.

SEWPAUL, V. 2010. Professionalism, postmodern ethics and global standards for social work education and training. Social Work/Maatskaplike Werk, 46(3):253-262.

SEWPAUL, V., MHONE, C. \& OSTHUS, I. (in press). Understanding rape and violence among children and youth living on the streets of Durban through the use of critical social research.

SHARMA, R.S. 2009. The monk who sold his Ferrari. United Kingdom: Element Books.

VIDYARTHI, V. \& WILSON, P. 2008. Development from within. Facilitating collective reflection for sustainable change. Virginia: Apex Foundation.

Prof Vishanthie Sewpaul, School of Social Work and Community Development, University of KwaZulu-Natal; Ms Ingrid Osthus, Master's candidate; Mr Christopher Kangawe Mhone, Master's candidate; School of Social Work and Community Development; University of KwaZulu-Natal, Durban, South Africa. 